\title{
'Rebranding' through Names: A New Revolution in the Malays' Identity Identification
}

\author{
Noraziah Mohd Amin \\ Academy of Language Studies \\ MARA University of Technology, Penang Campus, Malaysia \\ tinyfunnybunny7@gmail.com \\ Noor Azam Abdul Rahman \\ Department of Social Sciences \\ Universiti Tenaga Nasional, Putrajaya Campus, Malaysia \\ azamabdulrahman@yahoo.com
}

\section{Doi:10.5901/ajis.2013.v2n9p264}

\section{Abstract}

It is a common belief among Malays in Malaysia that someone's name will have a great influence upon the development of their personality. As for Malays who are Muslims in religion, some guidelines for naming a child are included in their religious teachings. The general practice of Malays in selecting names for their children involves the names in Arabic with some meaningful denotations. However, some Malay parents nowadays seem to ignore their Malay tradition and religious teachings in naming their children. This new practice of naming children among Malays apparently has signaled the process of 'rebranding' the Malays through their names that resemble English names which is currently pervasive in that community. Therefore, it is important for the perception of the Malays with their English-resembled names or à la English names to be examined because this seemingly new revolution in the identification of the Malays' identity can probably give rise to many problems in the sense of identity association via names.

Keywords: 'Rebranding', à la English names, Identity, Malays, Naming, Islam.

\section{Introduction}

Takkan Melayu hilang di dunia, which if translated literally means, 'It is unthinkable for the Malays to disappear from the face of the earth', is the famous saying of the legendary Malay warrior, Hang Tuah. Ismail Noor and Muhammad Azaham (2000) view the Malay adage as a truism, challenge for Malay future generations to preserve and promote the Malay spirit of enterprise and value system so that they will not be washed with time. It is perhaps impossible for the Malays to be an extinct race, but the disappearance of the Malays that were once recognized for some specific characteristics as their identity marker is possible to happen.

According to Shamsul Amri Baharuddin (2005), globalization has affected people's identity as local identity is now intimidated by the global identity. Hashim Musa (2001) claims that globalization that is experienced by many Islamic countries including Malaysia has contributed to the emergence of the community marked by their imitation, borrowing and reliance on the elements considered to be distinguished (superior) from the West. As a result of Western influence brought by globalization, there is a growing tendency among Malay parents in Malaysia today to name their children names that sound much like English names, despite their religious teachings that suggest Arabic names with beautiful meanings for the believers of Islam.

\subsection{Problem Statement}

The issue of 'rebranding' of the Malays through names that resemble English names, which the researchers wish to address as the 'à la English names', can perhaps cause a serious identity crisis for those with such names. This is a new revolution in the identity marking of the Malays that can invite a lot of confusion in terms of identification of the Malays, and thus investigating the perception of the Malays towards their à la English names is imperative. 


\subsection{Objectives}

The study basically aims to discern how the Malays who possess à la English names perceive their names and the identity they believe their names should represent. In summary, the main objectives of this research are as follows:

i. To identify Malay, UNITEN students' perception towards their names.

ii. To determine if there is any significant difference between the male and female Malay, UNITEN students in perceiving their names.

\subsection{Research Questions}

Based on its objectives, this study intends to obtain the answers to the following questions:

i. What is Malay, UNITEN students' perception towards their names?

ii. Is there any significant difference between the male and female Malay, UNITEN students in perceiving their names?

\subsection{Significance of the Study}

This study can serve as the answer to the arguable issue related to the apparently new trend among Malay parents to give their children names that resemble English names, particularly in association with how the individuals with such names view the function of their names in their identity representation. Besides, the perception towards à la English names between male and female Malays can make this study another source of information on gender studies.

\section{Literature Review}

\subsection{Definition of 'Malay'}

Barnard and Maier (2004) claim that the precise meanings of Malay or its equivalents, Melayu and Maleis have never been established and they never will be. On the other hand, Vickers (2004) believes that in practice, Malay is a fraught term. For this paper, the definitions of Malay discussed are restricted to those related to Malay as an identity marker of the people who meet the criteria to be categorized as such. One of the definitions is the one provided by Dewan Bahasa dan Pustaka (the main organization of Malay language in Malaysia) and the United Nations that refer to Malays as 'the aboriginal residents that speak Malay, are Muslims with respect to religion, and practice Malay tradition and custom. They are under the Sultanate ruling and they are the nation with a privilege status in Malaysia, and they abide by Islam' (Zuhaimy Ismail, 2009). According to Ismail Noor and Muhammad Azaham (2000, p. xi ), 'The Malay is a practicing Muslim, residing in Malaysia, whose roots go back to his ancestors of the Old Malacca Empire and of those who were the sons of the soil in the other parts of the Malay archipelago, stretching as far back in history as 3000 B.C.'

According to Hooker (2004), the constitutional definition of Malay as stated in Laws of Malaysia: Federal Constitution, Article 160 declares a Malay as 'a person who professes the religion of Islam, habitually speaks the Malay language, conforms to Malay custom and, was before Merdeka Day born in the Federation or in Singapore or born of parents one of whom was born in the Federation or in Singapore, or is on that day domiciled in the Federation or in Singapore; or is the issue of such a person.' To summarize, in describing Malay identity, the three main characteristics are: Malay language, Malay custom and Islam.

\subsection{Malays in Malaysia}

According to Shamsul Amri Baharuddin (2005), during the pre-colonial era in then Malaya (now known as Malaysia), collective identity was determined based on the place of origin. Vickers (2004) claims that any Malays in Malaysia are the descendents of the Malays from outside the Malay peninsula, or from Bugis and Minangkabau who came from the neighboring land, Indonesia. During the colonization of Malaya, the term Malay was used to categorize the Malayspeaking Muslims residing in the Peninsula and offshore islands from Indian and Chinese immigrants (Andaya \& Andaya, 1982). Clearly, Malays in Malaysia have been associated with Islam since before the independence of the country in 1957 and even after being granted independence, the colonized practice of defining the Malays was still continued as the definition was formalized in the Malayan Constitution. 
Vickers (2004) states that the ruling class of the nation state of Malaysia maintains a hegemonic Malay identity based on the difference between supposedly indigenous Islamic Malays and 'outsiders', namely Chinese and Indians. According to Vickers $(2004$, p. 27), 'Malay is meant to be coterminous with bumiputera, which in its literal meaning, 'sons of the soil' denotes the indigenous status of the Malays...' According to Mahathir bin Mohamad (2003a), in the history of the British administration of Malaya, the Malays were recognized by the British as the definitive people of Malaya. Besides, Malaya was also known as Tanah Melayu (Malayland) which this indicates that the existence of Malays as part of the identity of the region was long acknowledged (Abdul Ghani Othman, 2009). The Malays until today still represent the majority of the population of Malaysia.

\subsection{The Concept of Name, Identity Identification and Gender-related Perception}

The Malay proverb, 'Tigers die and leave their stripes, humans die and leave their names' obviously implies how important someone's name is. This is probably due to the fact that a person's name has a close tie to his self depending on what his name suggests in meaning. For instance, a person with a good name often tries to behave himself in order not to tarnish such a good name of his (Mohd Yusoff Abas, 2003).

The term, 'identity' is derived from the Latin, idem which literally means 'similarity' or 'continuity' (Shamsul Amri Baharuddin, 2005). Shamsul Amri Baharuddin (2005) in interpreting the concept of identity classifies it into: individual and collective identity. Theoretically, individual identity is confined to representing only a particular individual. Nevertheless, sociologically, the individual's characteristics that shape his identity are recognized by other people either formally or informally. As for collective identity, the similarities in some aspects between an individual and the others namely their language; culture such as their architectural designs and arts; religion and even their delicacies, are the measure for their shared identity. The collective identity of Malays among others is Islam. In relation to giving names to children, Islamic doctrine places great emphasis on naming a child as there is a belief that a human being shall be called by his name in life after death (Fatimah $\mathrm{Hj}$. Omar, 1995). A name then in Islamic perspective, is a critical identity identification of an individual as it covers both his worldly life and the hereafter. To illustrate, Arabic names are commonly connected to Muslims as such names are proposed by Islam. Thus, a name may also carry the religious association of a person.

Macoby (1990) argues that psychologically, gender similarities and differences are conditional that in some aspects, men and women are similar and in some other, they are different. However, most people believe, that there are important psychological attributes that distinguish men and women (Lueptow, Garovich-Szabo, \& Lueptow, 2001; Prentice \& Carranza, 2004; Chatard, Guimond, \& Selimbegovic, 2007). As for perception towards one's own name, perhaps each individual has his or her own view about it. 'Perception can be thought of as each individual's personal theory of reality, the knowledge gathering process that defines our view of the world' (Sekuler \& Blake, 2002, p. 12). Probably, there is the influence of gender that causes the differences in how males and females personally perceive their own names.

\subsection{Malays and Islamic Teachings in Naming}

Islam is a comprehensive religion. Its teachings encompass every aspect and cycle of human life even as early as a human being is born. From Prophet Muhammad, Samirah narrated, 'Slaughter (an animal) on the seventh day (of his birth), give him a good name and shave his head on the day' (Abdullah, 1990, p. 64). According to a hadith (the saying of Prophet Muhammad) narrated by Abu Dawud, the Prophet said, 'Surely you shall be called on the Day of Judgment by your name and your father's, so give (a child) a good name' (Fatimah Hj. Omar, 1995, p. 68). With respect to naming a child, Islam provides some guidelines for its believers as a hadith narrated by Abu Dawud and others mentions, 'Give the names of the prophets, and the names most loved by Allah are Abdullah and Abdul Rahman, and the most truthful are Haris and Hamman' (Fatimah Hj. Omar, 1995, p. 69). The core of a name in Islamic perspective is the meaning it conveys. Prophet Muhammad used to change the names, Harb and Muroh into Hassan and Husain as the former two names have negative meanings. As for the Malays' new revolution in naming a child that signals favoritism towards à la English names, they clearly seem to disregard their Islamic teachings, thus not making them easily identifiable with their Islamic names.

\subsection{Rebranding through Names in the Context of Malays' Identity Identification}

A brand is 'a specific name, symbol, or design that is used to distinguish a particular seller's product' (Doyle \& Stern, 2006, p.104). According to Davey and Jacks (2000), the functions of the brand name of a product are to say something 
about it and be responsible for creating its cachet value. Davey and Jacks (2000) believe that the idea behind branding a product is for the inventor or manufacturer to identify it as theirs, and for customers to identify it with the lifestyle it represents. As for rebranding of a product, this may involve the change of existing name, logo or packaging of the product (Lim, 2008). However, the 'rebranding' discussed in this paper refers to the seemingly growing inclination or preference among Malay parents to give à la English names to their children compared to Arabic names proposed by Islam that this apparently indicates a new revolution in their identity identification.

This issue is evidenced considering the names given by many Malay celebrities to their children nowadays that this seems to suggest even the public figures are experiencing this pervasively new shift in naming a child in the community. For instance, Malay artistes such as Que Haidar and Fauziah Latif used to receive criticisms from the media for their children's names, Cleopatra (Syazwan Zakariah, 2012), and Jeffrey Joaqium and Jeremy Jay (Khadijah Ibrahim, 2012). Two other celebrities, Faezah Elai and Norish Karman each named their child, Dealova (Amirah Amaly Syafaat, 2013) and Alexander ('Never argue about Haq's status- NK', 2012) respectively. Besides, Ning Baizura was also criticized for her son's name, Ryan Sky that was claimed not Islamic at all (Khadijah Ibrahim, 2013). Obviously, the 'rebranding' of Malays through names involves the selection of names from the West compared to the other parts of the world.

\subsection{Identity Transformation and Westernization}

Shamsul Amri Baharuddin (2005) claims, in identity transformation, the identity will go through some changes either it is static or dynamic. The changes in identity may occur because of the pressure from inside or outside a community. Most Social Science and History studies emphasize that the major agent for transforming the identity of the majority of humans in the world is westernization that comes together with colonization (Shamsul Amri Baharuddin, 2005). Modern living environment, especially on the arrival of the new millennium is beset by the distracting influences as a result of extensive global liberalization and permissiveness (Ismail Noor \& Muhammad Azaham, 2000). Shad Saleem Faruqi (2006, p. 25) mentions, 'We cannot retreat to the past and ignore present realities... We have to accept multiple identities. We have to show tolerance of others and yet not allow our identities as Muslims to be obliterated.' Clearly, despite the intensifying challenges to identity preservation brought by globalization at present, Muslims, Malays included should remain steadfast in their Islamic practices including child naming.

\section{Methodology}

\subsection{Research Design}

This study employed descriptive, quantitative research design using a questionnaire survey on the respondents' perception towards their names and the identity their names should represent.

\subsection{Sampling Method}

Non-probability sampling was employed where 30 respondents from the populations of Foundation and Bachelor's Degree students of Universiti Tenaga Nasional (UNITEN) were selected from the students' profiles database to represent the predetermined sample size of the study. The sample consisted of students with three main criteria: à la English names, Malay, and male/female. The researchers clearly conducted purposive sampling as such characteristics of the respondents were predefined with the judgment that these people could provide the best information to achieve the objectives of the study (Kumar, 2011).

\subsection{Participants}

There were 30 respondents participated in the study where 15 of them were male and another 15 were female. The respondents were within the age range of 18 to 23 years old.

\subsection{Instrument}

The questionnaire administered to the respondents consisted of 25 self-reporting statements that focused on how a person perceives his/her à la English name should represent, with regard to identity identification. The respondents' 
perception towards their given names was measured using five-point Likert Scale where a numerical value was assigned to each level of agreeing: Strongly disagree $=1$, Disagree $=2$, Undecided $=3$, Agree $=4$, and Strongly agree $=5$.

\subsection{Data Collection and Analysis}

The data for the main study was collected in one stage only which means there was no test-retest involved. Next, the quantitative data was entered into the Statistical Package for Social Sciences (SPSS) version 17.0 and was analyzed using this software.

\subsubsection{The Pilot Study}

A pilot study was conducted with 10 students (five males and five females) that aimed at testing the validity of the questionnaire to be used by the researchers including its reliability coefficient, and the clarity and comprehensibility of all items and instructions in it. The pilot study was conducted three weeks before the main study began.

\subsubsection{The Main Study}

The main study commenced with an introductory session with the respondents, where the researchers explained to them the purposes of the research to ensure they understood them, and clarified the instructions and meanings of technical terms included in the questionnaire to familiarize the respondents with the terms used. The time given for the students to fill in the questionnaire was two hours maximum. The participants involved in the pilot test managed to submit their completed questionnaire in less than one hour which this suggested that a-two hour duration for answering the items was appropriate.

\section{Findings and Analysis}

This section presents the data analysis of the study. The two fundamental goals of this research namely, to identify the respondents' perception towards their names, and to determine if there is any significant difference between the male and female respondents in perceiving their names, drove the collection of the data and the subsequent data analysis.

\subsection{Pilot Test}

\subsubsection{Internal Consistency}

Table 1: Cronbach's Alpha Reliability Coefficient for the Instrument

\begin{tabular}{|l|c|}
\multicolumn{2}{|c|}{$\mathrm{n}=10$} \\
\hline Perception towards name & Cronbach's Alpha Score \\
\hline 25 self-reporting statements & 0.763 \\
\hline
\end{tabular}

The participants in the pilot test responded to the 25 items in the questionnaire. The items used in measuring the construct demonstrated relatively good reliability when the Cronbach's alpha displayed the value, 0.763 (see Table 1). This figure represented an acceptable value that indicated the questionnaire was reliable to be utilized for the study as the reports about the acceptable values of alpha presented the range from 0.70 to 0.95 (Nunnally \& Bernstein, 1994; DeVellis, 2003).

\subsection{Main Test}

\subsubsection{Research Question 1: What is Malay, UNITEN students' perception towards their names?}

\subsubsection{Respondents' Overall Perception towards Names}


Table 2: Frequency (f) Distribution (in percentage) for the Respondents' Perception towards Names

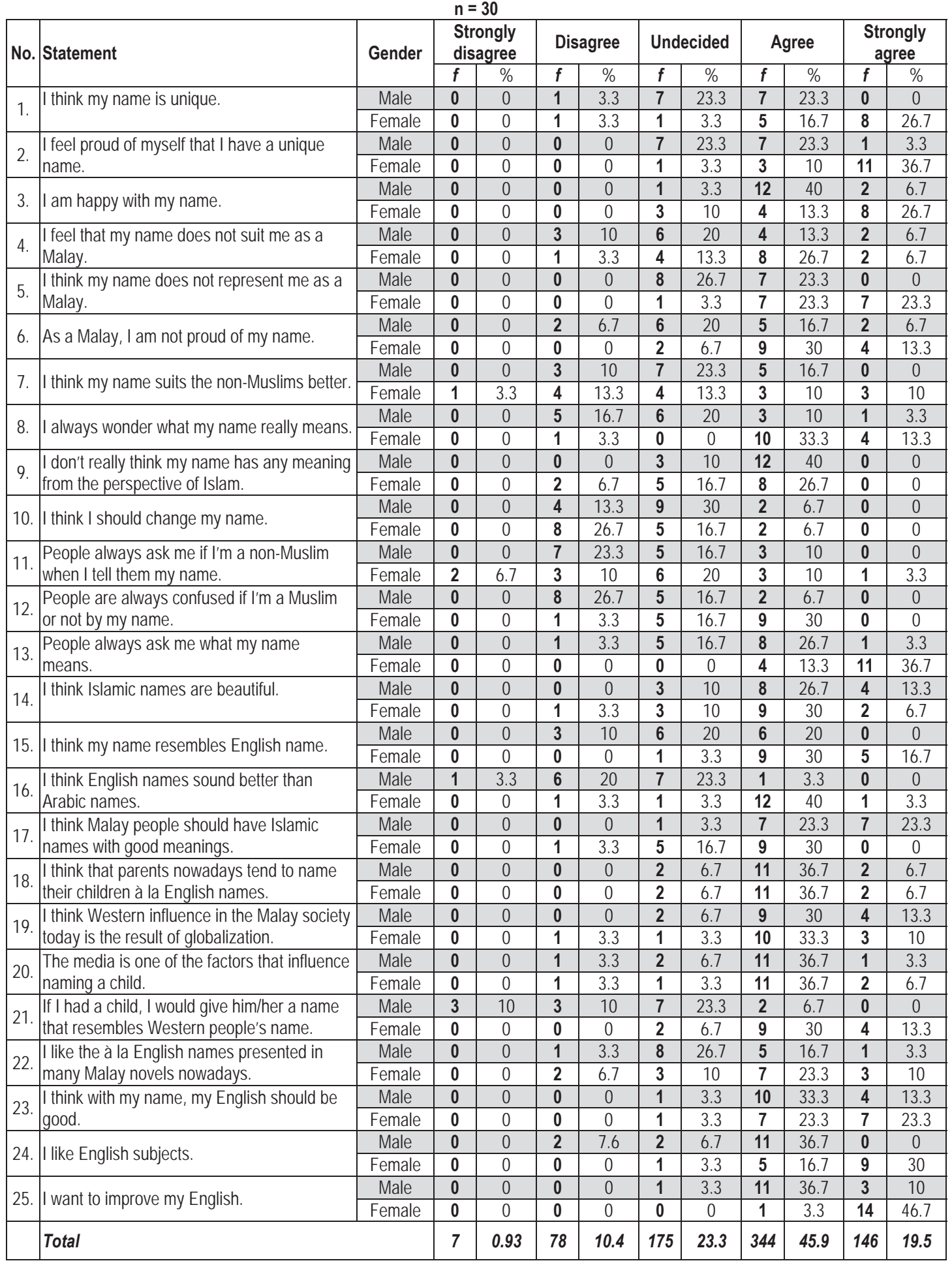


Table 2 above shows the frequency ( $f$ ) and percentage (\%) distribution for all items in the questionnaire that make up the respondents' perception towards their names. To answer Research Question 1, within the 'strongly disagree' to 'strongly agree' range, most of the respondents (45.9\%) assigned 'agree' to the 25 statements in the questionnaire. As for the other levels of agreement or disagreement, $19.5 \%$ of the participants strongly agreed, while only $0.93 \%$ of the respondents strongly disagreed with the items. The rest of the respondents, $10.4 \%$ and $23.3 \%$ of them assigned 'disagree' and 'undecided' to the items respectively.

Dividing the items into the pro and against à la English names, for the items that support possessing the names (item 1, 2, 3, 16, 21 and 22), there were more female respondents that indicated their agreement with the items compared to male, as there were 40 of them who reported they agreed, while 35 of them who revealed they strongly agreed with the items. 34 male respondents assigned 'agree' to the statements, while only four of them revealed they strongly agreed with the items. These numbers accounted for 38 male respondents in total compared to 75 female respondents in sum. For the items that can be considered as opposing à la English names to be possessed by Malays (item 4, 5, 6, 7, 9, 10, 14 and 17), again, the female participants accounted for the majority of respondents who selected 'agree' (55 respondents) and 'strongly agree' (18 respondents) for the items. The number of male respondents who reported they agreed with the items was 50 , while for the males who strongly agreed with the statements, the number was 15 . Of all the total percentage (23.3\%) for the response option, 'undecided', the participants who responded more to this were males as $15.6 \%$ of them assigned 'undecided' to the items. On the contrary, only $7.7 \%$ of female participants responded to such response option.

\subsubsection{Research Question 2: Is there any significant difference between the male and female Malay, UNITEN students in perceiving their names?}

\subsubsection{The Perception Towards Names between Male and Female Respondents}

Table 3: Independent Samples Test

$n=30$

\begin{tabular}{|c|c|c|c|c|c|c|c|c|}
\hline \multirow{3}{*}{ Item } & \multicolumn{8}{|c|}{ Independent Samples Test } \\
\hline & \multirow[b]{2}{*}{ Statement } & \multirow[b]{2}{*}{ Gender } & \multicolumn{6}{|c|}{ t-test for Equality of Means } \\
\hline & & & Mean & SD & $\mathrm{t}$ & df & $\begin{array}{l}\text { Sig. }(2- \\
\text { tailed) }\end{array}$ & $\begin{array}{c}\text { Mean } \\
\text { Difference }\end{array}$ \\
\hline \multirow[t]{2}{*}{1} & \multirow{2}{*}{ I think my name is unique. } & Male & 3.40 & .632 & \multirow{2}{*}{-3.287} & \multirow{2}{*}{28} & \multirow{2}{*}{.003} & \multirow{2}{*}{-.933} \\
\hline & & Female & 4.33 & .900 & & & & \\
\hline \multirow[t]{2}{*}{2} & \multirow{2}{*}{$\begin{array}{l}\text { I feel proud of myself that I have a unique } \\
\text { name. }\end{array}$} & Male & 3.60 & .632 & \multirow{2}{*}{-4.675} & \multirow{2}{*}{28} & \multirow{2}{*}{.000} & \multirow{2}{*}{-1.067} \\
\hline & & Female & 4.67 & .617 & & & & \\
\hline \multirow[t]{2}{*}{3} & \multirow{2}{*}{ I am happy with my name. } & Male & 4.07 & .458 & \multirow{2}{*}{-1.103} & \multirow{2}{*}{22.009} & \multirow{2}{*}{.282} & \multirow{2}{*}{-.267} \\
\hline & & Female & 4.33 & .816 & & & & \\
\hline \multirow[t]{2}{*}{4} & \multirow{2}{*}{$\begin{array}{l}\text { I feel that my name does not suit me as a } \\
\text { Malay. }\end{array}$} & Male & 3.33 & .976 & \multirow[t]{2}{*}{-1.228} & \multirow{2}{*}{28} & \multirow{2}{*}{.230} & \multirow{2}{*}{-.400} \\
\hline & & Female & 3.73 & .799 & & & & \\
\hline \multirow[t]{2}{*}{5} & \multirow{2}{*}{$\begin{array}{l}\text { I think my name does not represent me } \\
\text { as a Malay. }\end{array}$} & Male & 3.47 & .516 & -4.427 & & & \\
\hline & & Female & 4.40 & .632 & & 28 & .000 & -.933 \\
\hline 6 & & Male & 3.47 & .915 & & & & \\
\hline & As a Ivalay, I am not proud of my name. & Female & 4.13 & .640 & -2.312 & 28 & .028 & $-.66 /$ \\
\hline 7 & I think my name suits the non-Muslims & Male & 3.13 & .743 & & & & \\
\hline & better. & Female & 3.20 & 1.265 & -.176 & 28 & .862 & -.067 \\
\hline 8 & I always wonder what my name really & Male & 3.00 & .926 & & & & \\
\hline & means. & Female & 4.13 & .743 & -3.691 & 28 & .001 & -1.133 \\
\hline 9 & I don't really think my name has any & Male & 3.80 & .414 & & & & \\
\hline & meaning from the perspective of Islam. & Female & 3.40 & .737 & 1.833 & 28 & .071 & .400 \\
\hline 10 & & Male & 2.87 & .640 & & & & \\
\hline & I think I should change my name. & Female & 2.60 & .737 & 1.058 & 28 & .299 & $.26 /$ \\
\hline 11 & People always ask me if I'm a non- & Male & 2.73 & .799 & & & & \\
\hline & Muslim when I tell them my name. & Female & 2.87 & 1.125 & -.374 & 28 & .711 & -.133 \\
\hline 12 & People are always confused if I'm a & Male & 2.60 & .737 & & & & \\
\hline & Muslim or not by my name. & Female & 3.53 & .640 & -3.104 & 28 & .001 & -.933 \\
\hline
\end{tabular}




\begin{tabular}{|c|c|c|c|c|c|c|c|c|}
\hline \multirow[t]{2}{*}{13} & \multirow{2}{*}{$\begin{array}{l}\text { People always ask me what my name } \\
\text { means. }\end{array}$} & Male & 3.60 & .737 & \multirow[b]{2}{*}{-5.060} & \multirow{2}{*}{28} & \multirow{2}{*}{.000} & \multirow{2}{*}{-1.133} \\
\hline & & Female & 4.73 & .458 & & & & \\
\hline \multirow[t]{2}{*}{14} & \multirow{2}{*}{ I think Islamic names are beautiful. } & Male & 4.07 & .704 & \multirow{2}{*}{.987} & \multirow{2}{*}{28} & \multirow{2}{*}{.332} & \multirow{2}{*}{.267} \\
\hline & & Female & 3.80 & .775 & & & & \\
\hline \multirow[t]{2}{*}{15} & \multirow{2}{*}{$\begin{array}{l}\text { I think my name resembles English } \\
\text { name. }\end{array}$} & Male & 3.20 & .775 & \multirow{2}{*}{-4.233} & \multirow{2}{*}{28} & \multirow{2}{*}{.000} & \multirow{2}{*}{-1.067} \\
\hline & & Female & 4.27 & .594 & & & & \\
\hline \multirow[t]{2}{*}{16} & \multirow{2}{*}{$\begin{array}{l}\text { I think English names sound better than } \\
\text { Arabic names. }\end{array}$} & Male & 2.53 & .743 & \multirow{2}{*}{-5.265} & \multirow{2}{*}{28} & \multirow{2}{*}{.000} & \multirow{2}{*}{-1.333} \\
\hline & & Female & 3.87 & .640 & & & & \\
\hline \multirow[t]{2}{*}{17} & \multirow{2}{*}{$\begin{array}{l}\text { I think Malay people should have Islamic } \\
\text { names with good meanings. }\end{array}$} & Male & 4.40 & 632 & \multirow{2}{*}{3.731} & \multirow{2}{*}{28} & \multirow{2}{*}{.001} & \multirow{2}{*}{.867} \\
\hline & & Female & 3.53 & 640 & & & & \\
\hline \multirow{2}{*}{18} & \multirow{2}{*}{$\begin{array}{l}\text { I think that parents nowadays tend to } \\
\text { name their children à la English names. }\end{array}$} & Male & 4.00 & 535 & ח00 & 28 & & \\
\hline & & Female & 4.00 & .535 & . & 28 & 1.000 & 0.000 \\
\hline 19 & I think Western influence in the Malay & Male & 4.13 & 640 & 521 & 28 & 606 & 132 \\
\hline & society today is the result of globalization. & Female & 4.00 & .756 & .521 & 28 & .600 & .133 \\
\hline 20 & The media is one of the factors that & Male & 3.80 & 676 & -529 & 28 & 601 & -133 \\
\hline & influence naming a child. & Female & 3.93 & .704 & -.029 & $\angle 0$ & .001 & -.133 \\
\hline 21 & If I had a child, I would give him/her a & Male & 2.53 & 990 & & & & \\
\hline & $\begin{array}{l}\text { name that resembles Western people's } \\
\text { name. }\end{array}$ & Female & 4.13 & 640 & -5.255 & 28 & .000 & -1.600 \\
\hline 22 & I like the à la English names presented in & Male & 3.40 & .737 & & & & \\
\hline & many Malay novels nowadays. & Female & 3.73 & .961 & -1.066 & 28 & .296 & -.333 \\
\hline 23 & I think with my name, my English should & Male & 4.20 & 561 & 017 & 28 & 267 & 200 \\
\hline & be good. & Female & 4.40 & 632 & -.911 & 28 & .361 & -.200 \\
\hline 24 & I like Enalish subiects & Male & 3.60 & .737 & 3704 & 28 & 001 & -933 \\
\hline & fo ne Engnisil sujuecis. & Female & 4.53 & 640 & -3.104 & $\angle 8$ & .001 & -.933 \\
\hline 25 & I want to improve my English. & Male & 4.13 & .516 & -5367 & 28 & 000 & -800 \\
\hline & 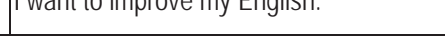 & Female & 4.93 & 258 & & & & \\
\hline
\end{tabular}

An independent-samples t-test was conducted to compare the male respondents' perception towards their names with the one of female respondents. The items highlighted (item $3,4,7,9,10,11,14,18,19,20,22$, and 23) in Table 3 above show no significant difference between male and female respondents judging by their mean scores and significant values as their $p$ - values were $>.05$. For example, item 3 ('I am happy with my name') presented no significant difference between male $(M=4.07, S D=.458)$ and female respondents $(M=4.33, S D=.816) ; t(22)=-1.103$, as the significant 2tailed value generated was $p=.282$. Whereas, the remaining items (item $1,2,5,6,8,12,13,15,16,17,21$, 24, and 25) showed a significant difference, considering their mean scores and 2-tailed significant values as their $p$ - values were $<.05$ (Creswell, 2008). For instance, the result for item 1 ('I think my name is unique') revealed a significant difference between male $(M=3.40, S D=.632)$ and female respondents $(M=4.33, S D=.900) ; t(28)=-3.287$, and $p=.003$. To summarize, there were some significant differences in the responses provided by male and female participants, and this among others involved items pertaining to presenting Malay identity through names, the meaning of their names, and planning the names of their future children.

\section{Discussion}

Clearly, most of the female respondents favor à la English names as they even intend to name their children such names. This seems to signal that a new revolution of the 'rebranding' of the next generation is likely to occur. To support this prediction, the majority of female respondents perceive English names sound better than Arabic names. Perhaps, this is one reason why they prefer to name their future children à la English names. Ironically, despite their preference for à la English names, they always wonder what their names mean, and also admit that Malay people should have Islamic names with good meanings. Apparently, they seem to have a crisis with sticking to one identity with regard to their names. Besides, it seems that when not being identified as of any racial group, the majority of male and female respondents are proud of their names. However, when they are identified as Malays, most of the respondents feel the opposite. The respondents are likely to experience a crisis as they seem to be unsure whether they should be happy with their identity as Malays with à la English names, or with their identity as simply individuals with such names. Perhaps, the 'rebranding' of Malays via à la English names occurs as a result of Western influence that comes together with globalization as indicated by the majority of the respondents. Probably, this is true as according to the former Prime 
Minister of Malaysia, Mahathir bin Mohamad (2003b, p. 116), 'Human beings in $21^{\text {st }}$ century will witness the new world: the world that has become so small that there are no longer boundaries. We were informed that with information technology, we would face the world without any boundary.' Based on this premise, the media that is part of information technology perhaps is responsible for influencing the naming of a child as reported by the respondents in majority.

\section{Conclusion}

The results of this study perhaps can be considered by Malay parents in naming their children to help them picture the possible experiences that their children would go through, and the perception they would form about their names if they own à la English names. Apart from the perception of the Malay people towards their à la English names, the perception of other people towards such names is also significant to be paid attention to in order to get their general idea about the names. Besides, an extensive research can be conducted for the purpose of discovering more about the real crisis likely to be experienced by Malay people regarding their identity identification via their à la English names. Also, the other causal factors for such a new 'rebranding' through names among Malays are significant to be investigated apart from the media and globalization as the reasons highlighted in the present research. Nevertheless, this study can serve as another source of information on naming among Malays in Malaysia.

\section{References}

Abdul Ghani Othman. (2009). Hidup Melayu bersatu. Johor: Pejabat Menteri Besar Johor (Unit Media dan Komunikasi).

Abdullah Nashih Ulwan. (1990). Pedoman pendidikan anak-anak dalam Islam Jilid 1-2. Klang, Malaysia: Klang Book Centre.

Amirah Amaly Syafaat. (2013, April 14). Faezah Elai kembali aktif. Retrieved May 20, 2013 from http://www.utusan.com.my/utusan/Hiburan/20130414/hi_01/Faezah-Elai-kembali-aktif

Andaya, B. W., \& Andaya, L. (1982). A history of Malaysia. London: Macmillan.

Barnard, T. M., \& Maier, H. M. J. (2004). Melayu, Malays, Maleis: Journeys through the identity of a collection. In Timothy P. Barnard $(\mathrm{Ed})$, Contesting Malayness: Malay identity across boundaries (pp. ix-xii). Singapore: Singapore University Press.

Chatard, A., Guimond, S., \& Selimbegovic, L. (2007). 'How good are you in math?' The effect of gender stereotypes on students' recollection of their school marks. Journal of Experimental Social Psychology, 43, 1017-1024.

Creswell, J. W. (2008). Educational research: Planning, conducting, and evaluating quantitative and qualitative research (3rd ed). New Jersey: Pearson Education Inc.

Davey, R., \& Jacks, A. (2000). How to be better at marketing. London: Kogan Page Limited.

DeVellis, R. (2003). Scale development: theory and applications: theory and application. Thousand Okas, CA: Sage.

Doyle, P., \& Stern, P. (2006). Marketing management and strategy (4th ed). Essex, England: Pearson Education Limited.

Fatimah Hj. Omar. (1995). Anak 'amanah Allah'. Kuala Lumpur: Al Hidayah Publisher.

Hashim Musa. (2001). Merekonstruksi tamadun Melayu Islam ke arah pembinaan sebuah tamadun dunia alaf ketiga. Teks Syarahan Perdana sebagai Pengiktirafan Jawatan Profesor di Universiti Malaya. Kuala Lumpur: Penerbit Universiti Malaya.

Ismail Noor., \& Muhammad Azaham. (2000). The Malays par excellence...warts and all: An introspection. Selangor: Pelanduk Publications (M) Sdn. Bhd.

Khadijah Ibrahim. (2012, July 4). Jee disuruh cari teman lelaki. In Mega pp. 26-27, Akhbar Utusan Malaysia. Kuala Lumpur: Utusan Publication \& Distributors.

Khadijah Ibrahim. (2013, February 2). Ning Baizura jelaskan maksud nama anak. Retrieved May 20, 2013 from http://www.utusan.com.my/utusan/Hiburan/20130206/hi_05/Ning-Baizura-jelaskan-maksud-nama-anak

Kumar, R. (2011). Research methodology: A step-by-step guide for beginners. Los Angeles: SAGE.

Lim Kok Wing, 2008. Abdullah: Memperkasa Malaysia. Cyberjaya: Limkokwing Integrated Sdn. Bhd.

Lueptow, L. B., Garovich-Szabo, L., \& Lueptow, M. B. (2001). Social change and the persistence of sex typing, 1974-1997. Social Forces, 80, 1-36.

Maccoby, E. E. (1990). Gender and relationships: A developmental account. American Psychologist, 45, 513-520.

Mahathir bin Mohamad. (2003a). The Malay dilemma. Singapore: Times Books International.

Mahathir bin Mohamad. (2003b). Politik, demokrasi dan Asia baru: Ucapan pilihan Dr. Mahathir Mohamad Perdana Menteri Malaysia. Kuala Lumpur: Institut Terjemahan Negara Malaysia Berhad.

Mohd Yusoff Abas (Ed). (2003). 1001 nama Islam pilihan. Kuala Lumpur: Malaysian Da'wah Islamiyah Foundation.

Nunnally, J., \& Bernstein, L. (1994). Psychometric theory. New York: McGraw-Hill Higher, INC.

Prentice, D. A., \& Carranza, E. (2004). Sustaining cultural beliefs in the case of their violation: The case of gender stereotypes. In M. Schaller \& C. S. Crandall (Eds.), The Psychological Foundations of Culture (pp. 259-280), London: Lawrence Erlbaum Associates.

Shad Saleem Faruqi. (2006). Islam, democracy and development. Monograph series No. 1/2006. Shah Alam: University Publication Centre (UPENA). 
Shamsul Amri Baharuddin. (2004). A history of an identity, an identity of a history: The idea and practice of 'Malayness' in Malaysia reconsidered. In Timothy P. Barnard (Ed), Contesting Malayness: Malay identity across boundaries (pp. 135-148). Singapore: Singapore University Press.

Shamsul Amri Baharuddin. (2005). Wacana mengenai identiti Melayu: Dari 'academic analyses' ke 'public advocacy.' In Ahmad Murad Merican (Ed), Pemikiran Melayu: Dialog meja bulat (pp. 63-90). Selangor: Pusat Sejarah Intelektual dan Pemikiran Melayu (CENTIS).

Syazwan Zakariah. (2012, October 29). Mohon Jangan Persoal Nama Anak. [Gala TV]. In 30 minutes. Kuala Lumpur, Malaysia: Astro Malaysia Holdings Berhad.

Usah pertikai status Haq- NK. (2012, August 21). In Mega, pp. 2-3, Akhbar Utusan Malaysia. Kuala Lumpur: Utusan Publication \& Distributors.

Vickers, A. (2004). 'Malay identity': Modernity, invented tradition and forms of knowledge. In Timothy P. Barnard (Ed), Contesting Malayness: Malay identity across boundaries (pp. 25-55). Singapore: Singapore University Press.

Zuhaimy Ismail. (2009). Melayu dan perjuangan. Kuala Lumpur: Madina Press. 